\title{
Myndighetsutøver, ressursforvalter og livredder - den russiske kystvakten i støpeskjeen
}

\author{
Kristian Åtland ${ }^{\star}$ \\ $\mathrm{PhD}$, forsker ved Forsvarets forskningsinstitutt $(\mathrm{FFI})$
}

\begin{abstract}
The Russian Coast Guard, or Beregovaya okhrana, was formally established in 2007 and plays a crucial role in the management of natural resources located in the vast maritime areas under Russian jurisdiction. The purpose of this article is to shed light on the Coast Guard's organisation, capabilities and operations in the maritime areas that surround the Russian Federation, and to discuss the service's ability to effectively perform its missions, now and in the period up to 2020. Special emphasis is placed on the situation in the northern waters. In the Barents Sea, the Russian Coast Guard cooperates closely with its Norwegian counterpart. This cooperation has existed for a long time, and it has not been adversely affected by the general deterioration of Russian-Western relations after Russia's 2014 intervention in Ukraine and the subsequent freeze in military-to-military cooperation. The article argues that Norway and Russia have a common interest in continuing the cooperation on non-military issues such as maritime search and rescue, fisheries management and law enforcement at sea.
\end{abstract}

Keywords: Coast Guard, Barents Sea, fisheries management, Norway-Russia relations, FSB

Denne artikkelen vil se nærmere på den russiske kystvaktens organisering og operative virksomhet, samt forholdet mellom den russiske og andre lands kystvakter, i de ulike kyst- og havområdene som omgir Den russiske føderasjon. Situasjonen i de nordlige havområder og innholdet $\mathrm{i}$ det norsk-russiske kystvaktsamarbeidet vil i denne forbindelse bli viet særlig oppmerksomhet. Det overordnede spørsmål som artikkelen søker å gi svar på, er om den russiske kystvakten i årene som kommer vil være i stand til å løse de oppgaver som den er pålagt, gitt sin nåværende organisasjonsmodell, styrkestruktur og modus operandi. Artikkelen søker også å belyse den rollen som bilateralt og regionalt kystvaktsamarbeid spiller - og vil kunne spille - $\mathrm{i}$ håndteringen av de formidable forvaltningsutfordringene som Russland og nabolandene, inkludert Norge, står overfor i de aktuelle havområdene.

^Kontaktinformasjon: Kristian Åtland. Email: kristian.atland@ffi.no 
Russlands store og stedvis svært ressursrike kyst- og havområder i nord, øst, sør og vest er viktige arenaer for maritim næringsvirksomhet, herunder fiskerier, kommersiell skipstrafikk og offshore petroleumsvirksomhet. Russlands økonomiske sone omfatter ifølge russiske kilder et havområde på over 8 millioner kvadratkilometer (Boltenkov 2013: 27). Dette innebærer at kun tre land har økonomiske soner som er større enn Russlands. ${ }^{1}$ Det maritime domenets relative betydning som kilde til fremtidig økonomisk vekst og utvikling vurderes på politisk hold som stor og økende, noe som også gjenspeiles i Russlands nylig vedtatte maritime doktrine (jf. Pettersen 2015) og landets Arktis-strategi, vedtatt i 2008 (Pravitel'stvo Rossijskoj Federatsii 2008).

De globale klimaendringene, issmeltingen i Polhavet og nyvinninger innenfor skips- og offshoreteknologi vil i fremtiden kunne muliggjøre helårs skipstrafikk og ressursutvinning i områder som tidligere var helt eller delvis isdekte. Russlands planlagte utvidelse av sin arktiske kontinentalsokkel utenfor 200 nautiske mil må ses i denne sammenheng. Dersom Russland får gjennomslag for sitt nylig fremlagte sokkelkrav i Arktis, vil landet kunne få råderett over et 1,2 millioner kvadratkilometer stort sokkelområde i Polhavet (Korostikov 2015). Etter hvert som de marine ressursene i andre havområder uttømmes eller forflytter seg nordover på grunn av økende vanntemperatur, vil de marine ressursene i deler av Russlands økonomiske sone, eksempelvis i Barentshavet, Japanhavet og det nordlige stillehav, kunne bli utsatt for økende press. En slik utvikling vil kunne stille store krav til Russlands evne til å drive effektiv myndighetsutøvelse og ressursforvaltning i egne jurisdiksjonsområder, og ikke minst det bilaterale og regionale samarbeidet som Russland har med andre kyststater, deriblant Norge.

Den russiske kystvakten har utvilsomt en viktig rolle å spille i ivaretakelsen av Russlands økonomiske og andre interesser i det maritime domenet, og i koordineringen av andre russiske etaters og aktørers virksomhet i landets store sokkel- og havområder. Hvorvidt Russland $\mathrm{i}$ årene som kommer vil lykkes med å optimalisere utnyttelsen av naturressursene som befinner seg i disse områdene og samtidig klare å bevare det marine miljøet og den langsiktige økologiske balansen, vil i stor grad avhenge av kystvaktens kapasiteter og evne til oppgaveløsning. Ressursforvaltning, fiskerioppsyn og ivaretakelse av sikkerheten til de som til enhver tid ferdes eller har sitt daglige virke på sjøen er oppgaver som forutsetter en adekvat tilstedeværelse på sjøen, som igjen forutsetter at tidsriktige fartøyer er tilgjengelig for slik tjeneste. Fremfor alt forutsetter det at kystvakten er organisert på en hensiktsmessig måte og at den evner å samarbeide med beslektede tjenester i andre land når det er behov for det.

Artikkelen begynner med en kort presentasjon av den russiske kystvaktens opprinnelse og tar deretter for seg kystvaktens nåværende plass i det russiske maktapparatet på føderalt og regionalt nivå, det juridiske rammeverket den opererer innenfor og rollefordelingen mellom kystvakt og marine. Deretter følger en diskusjon av den russiske kystvaktens operative virksomhet i ulike operasjonsteatre, med særlig

\footnotetext{
${ }^{1}$ USA, Frankrike (inkludert «sørterritoriene») og Australia.
} 
vekt på de nordlige havområder. Den påfølgende seksjonen ser nærmere på innholdet $i$, og erfaringene med, det norsk-russiske kystvaktsamarbeidet og utsiktene for en videreutvikling av dette i perioden frem mot 2020. Avslutningsvis gis en oppsummering av studiens hovedfunn, med særlig vekt på spørsmålet om den russiske kystvaktens nåværende og fremtidige evne til oppgaveløsning.

Ettersom det finnes få, om noen, akademiske studier av artikkelens tema, vil analysen nødvendigvis måtte basere seg på et kildemateriale som i utgangspunktet verken er spesielt omfangsrikt eller detaljrikt. Materialet inkluderer blant annet informasjon som er tilgjengelig på FSBs og grensevakttjenestens hjemmesider eller som kan trekkes ut av russiske strategidokumenter. Tidligere publiserte intervjuer med den russiske kystvaktens ledelse vil også bli lagt til grunn. FSBs råd for samfunnskontakt utgir et månedstidsskrift kalt FSB: Za $i$ protiv, som inneholder mye interessant stoff. Særlig gjelder dette et temanummer om kystvakten som ble utgitt i 2012 (FSB 2012). Studien baserer seg også på intervjuer og uformelle samtaler som forfatteren har hatt med russiske forskere og forsvarsjournalister i Moskva, norske forskerkolleger i Oslo og den norske kystvaktens ledelse på Sortland.

\section{Den russiske kystvaktens opprinnelse og organisering}

Den russiske kystvakten, eller Beregovaja okhrana, ble formelt etablert i sin nåværende form i 2007. Den er administrativt underlagt FSBs grensevakttjeneste, og base- og ledelsesstrukturen er i stor grad knyttet til de regionale grensedirektoratene. Kystvakten og dens fartøyer inngår med andre ord ikke i strukturene som er underlagt Forsvarsministeriet, iallfall ikke i fredstid. Kystvakten er i dag først og fremst et rettshåndhevende instrument, og den har en noe annen organisering, innretning og virkemåte enn hva KGBs maritime grensevaktstyrker hadde under den kalde krigen. Mens den sovjetiske sjøgrensevakten primært var innrettet mot å hindre grensekrenkelser på sjøen, og gjerne ble betraktet som «a Soviet Navy reserve for wartime» (Boltenkov 2013: 28), har dagens russiske kystvakt en langt bredere oppgaveportefølje, hvor opprettholdelse av «order at sea» og tilretteleggelse for miljømessig forsvarlig ressursutnyttelse er temaer som vies stor og økende oppmerksomhet.

Beslutningen om å bygge opp en «moderne» kystvakt underlagt FSBs grensevakttjeneste kan tolkes som uttrykk for et ønske om å effektivisere, profesjonalisere og «demilitarisere» Russlands utøvelse av kyststatsjurisdiksjon og, i forlengelsen av dette, legge til rette for et konstruktivt samarbeid med nabolandene på områder av felles interesse. Den russiske kystvaktens øverste sjef, viseadmiral Jurij Aleksejev, er både stedfortredende sjef for FSBs grensevakttjeneste og sjef for grensevakttjenestens kystvaktavdeling. Hans første stedfortreder, og nestsjef for kystvaktavdelingen, er kontreadmiral Aleksej Vol'skij.

På det regionale nivået følger den russiske kystvaktens organisasjons- og ledelsesstruktur i store trekk grensevakttjenestens, med regionalt baserte «direktorater» i de russiske grenseregionene. I Murmansk ledes FSBs grensedirektorat, som har ansvar for hele det vestlige Arktis (det vil si kyst-, hav- og sokkelområdene mellom den norsk-russiske grensen $\mathrm{i}$ vest og Tajmyrhalvøya $\mathrm{i} ø \mathrm{st})$, av generalmajor Igor 
Konstantinov (Desnitskaja 2015). Han har også det overordnede ansvar for aktivitetene til kystvakten og andre underliggende tjenester lokalisert i embetsdistriktet. Det eneste unntaket er den landoperative grensevakten på Kola. Denne er etter en omorganisering i april 2015 administrativt underlagt grensedirektoratet i republikken Karelen, som har sitt hovedkvarter i Petrozavodsk (ibid.)

FSB har ifølge sin offisielle nettside 39 regionale grensedirektorater (pogranitsjnye upravlenija). Disse er spredt over hele territoriet til Den russiske føderasjon, langs føderasjonens yttergrenser så vel som i innlandet. ${ }^{2}$ Mellom 14 og 16 av de 39 grensedirektoratene (Pavlova 2009: 7; Nikolsky 2013: 24) har ansvar for maritime områder (hav, kystfarvann, innsjøer og større elver) og er av denne grunn oppsatt med kystvaktenheter. Enhetenes fartøyer patruljerer og overvåker sine ansvarsområder og ivaretar et stort antall oppgaver i disse, det vil si i russisk territorialfarvann, russisk indre farvann, russisk økonomisk sone, på russisk kontinentalsokkel og i internasjonale farvann. Virksomheten ledes vanligvis fra koordineringssentre underlagt FSBs regionale grensedirektorater og utøves gjerne i samråd med andre russiske etater, eksempelvis Det føderale fiskeribyrået (Rosrybolovstvo), og/eller samarbeidende utenlandske tjenester, i første rekke nabolandenes kystvakter. Koordineringssenteret for operasjonene i Barentshavet ligger i Murmansk.

Ansvaret for forvaltning av - og kontroll med - Russlands marine bioressurser lå på 1990-tallet hos russiske fiskerimyndigheter, som periodevis også var underlagt Landbruksministeriet (for detaljer, se Hønneland 2003: 2). Sett fra et ressursforvaltningsperspektiv var dette en blandet erfaring, kjennetegnet ved utstrakt korrupsjon og et betydelig overfiske av fastsatte kvoter. Informasjon fra den norske kystvakten indikerte tidlig på 1990-tallet at den russiske torskekvoten i Barentshavet ble overfisket med nærmere 60\% (Jørgensen \& Hønneland 2013: 359). I 1997-1998 ble ansvaret for kontrollvirksomheten i russisk økonomisk sone i sin helhet overført fra fiskeribyrået til den føderale grensevakttjenesten, som på dette tidspunkt var direkte underlagt presidenten. ${ }^{3}$ Da grensevakttjenesten i 2003 ble innlemmet i FSB, fulgte nevnte funksjoner med. Arbeidet med å rydde opp i den russiske fiskerinæringen og bekjempe tyvfiske og miljøkriminalitet i landets maritime jurisdiksjonsområder er blitt videreført og intensivert på 2000-tallet, kanskje særlig etter 2007 (Sytsjeva 2011).

Samtidig med at den russiske kystvakten begynte å ta form rundt 2007, ble det gjennomført en gjennomgripende modernisering av den statlige sjøinspeksjonen, Gosudarsvennaja morskaja inspektsija (heretter GMI). GMI fikk ny ledelse, fagkompetanse ble gradvis bygget opp, nye prosedyrer ble innført, tjenesten ble tilført nytt personell og tjenestemennene fikk offisersgrader. Endringen er av fagfolk blitt omtalt som GMIs «annen fødsel» (Putejev 2008: 33). Sjøinspeksjonen står i dag for planlegging og gjennomføring av fiskeriinspeksjoner i russisk økonomisk sone, i tillegg

\footnotetext{
${ }^{2}$ Et interaktivt kart over grensedirektoratene er tilgjengelig på http://ps.fsb.ru/regions.htm (lest 23. desember 2015).

${ }^{3}$ Myndighetsoverføringen skjedde ved presidentdekret no. 950 av 29. august 1997 og regjeringsbeslutning no. 90 av 26. januar 1998. De to dokumentene er tilgjengelig i fulltekst (på russisk) på henholdsvis http://base.garant.ru/11801386/ og http://base.garant.ru/12108640/ (lest 23. desember 2015).
} 
til å utøve flaggstatskontroll i tilstøtende farvann og delta i kontrollvirksomhet i internasjonale farvann, basert på internasjonale avtaler. Sjøinspeksjonen er som andre deler av kystvakten underlagt grensevakttjenesten, på føderalt så vel som på regionalt nivå. Det inngår med andre ord i funksjonene til kystvaktavdelingen ved FSBs grensevakttjeneste i Moskva å legge til rette for, og føre oppsyn med, GMIs kontrollvirksomhet (Manakov 2012: 15).

Parallelt med etableringen av GMI ble det på føderalt nivå utarbeidet og vedtatt et juridisk rammeverk for virksomheten, herunder et administrativt regelverk samt instrukser og prosedyrer for kontroll- og inspeksjonsvirksomhetens utførelse (Putejev 2012: 21). Føderal lovgivning ble på flere punkter endret, og hovedtyngden av endringene hadde som siktemål å skape et mer funksjonelt juridisk-administrativt grunnlag for bærekraftig ressursutnyttelse. Man ønsket å ansvarliggjøre fiskerne og fiskerinæringen som helhet og samtidig styrke myndighetenes sanksjonsmuligheter (oppbringelse, tilbakeholdelse, bøtelegging, beslag etc.) ved brudd på kvotevilkårene eller andre regler. Med henblikk på sistnevnte punkt ble det blant annet vedtatt betydelige endringer $\mathrm{i}$ «Lov om administrative lovbrudd» (Kodeks ob administrativnykh pravonarusjeniakh) sommeren $2011 .^{4}$

Den russiske kystvakten, inkludert GMI, er i dag en helprofesjonell tjeneste uten innslag av vernepliktige. Personellet rekrutteres i all hovedsak fra FSBs egne utdanningsinstitusjoner, spesielt kystvaktinstituttet i Anapa ved Svartehavet (Institut beregovoj okhrany FSB Rossii), som ble opprettet i 2007. Det første opptaket til et nytt kystvaktkurs av to år og ti måneders varighet ble gjennomført i 2008. Offiserer herfra tjenestegjør allerede på kystvaktens fartøyer. Kystvaktinstituttet utdanner også personell til GMI. Sistnevnte studium har en noe mer juridisk innretning (med fokus på nasjonal lovgivning og internasjonal havrett) enn de øvrige, som primært er innrettet mot temaer som maskinlære, manøvrering, radiokommunikasjon, bruk av automatiserte informasjons- og ledelsessystemer etc. ( $N a$ strazje Zapoljar'ja 9. desember 2009). I 2010-2011 ble det ifølge GMI-sjefen i Murmansk utdannet 40 nye inspektører ved instituttet i Anapa (Putejev 2012: 22). Selv om det russiske kystvaktinstituttet fortsatt må sies å være i en oppbyggingsfase, skal grunnutdanningen i Anapa ifølge russiske kilder være av god kvalitet. Instituttet driver også videreutdanning av kystvaktens og GMIs personell, på midlere og høyere nivå.

Når det gjelder kystvaktens fartøyer, er det fortsatt stort behov for fornyelse. Mange av fartøyene som inngår i dagens struktur, er bygget på 1970- og 80-tallet, og kun et fåtall av dem er helikopterbærende. Kystvaktens ledelse har etter beste evne forsøkt å få fortgang i arbeidet med å bygge nye fartøyer og helikoptre som kan erstatte eller supplere elementene som inngår i dagens struktur. Kystvaktens anskaffelsesplan for perioden frem mot 2020 (omtalt i Sjasjkov 2012) har vært under implementering i noen år, og en del nye fartøyer er blitt bygget, særlig av de mindre klassene. Den russiske kystvaktens operative evne i nord vil bli forsøkt styrket i årene

\footnotetext{
${ }^{4}$ Innholdet i lovendringen fremgår av http://www.garant.ru/products/ipo/prime/doc/12087856/ (lest 23. desember 2015). Kort fortalt dreier det seg om en styrking av statens sanksjonsmuligheter overfor tyvfiskere, det være seg russiske eller utenlandske.
} 
som kommer, spesielt gjennom den pågående anskaffelsen av nye patruljefartøyer av den såkalte Okean-klassen (Jegorov 2015). Andelen moderne fartøyer i kystvaktens struktur ble i 2012 anslått til 26\% (Sjasjkov 2012). Den russiske verftsindustriens leveringsevne er begrenset, blant annet på grunn av parallelt pågående bygge- og vedlikeholdsprosjekter i regi av den russiske marine, og det må fortsatt påregnes forsinkelser i implementeringen av kystvaktens anskaffelsesplan. Dette tilsier at arbeidet med å bygge opp en moderne og optimalt utstyrt kystvaktflåte nok vil ta atskillig lengre tid enn opprinnelig antatt.

\section{Operativ virksomhet}

Den russiske kystvaktens fartøyer er organisert i skvadroner og opererer fra baser i blant annet Murmansk, Arkhangelsk, Petropavlovsk-Kamtsjatskij (Kamtsjatka), Sjikotan (Kurilene), Korsakov (Sakhalin), Nakhodka, Vladivostok, Astrakhan', Kaspijsk, Sotsji, Novorossijsk, Temrjuk, Kaliningrad og Vysotsk (Boltenkov 2013: 28). Det finnes også et antall baser for fartøyene som patruljerer de russiske elvene, blant annet i Pskov og Khabarovsk (ibid.). Den russiske kystvaktens operative virksomhet har økt siden 2007, både i omfang og kompleksitet, og kontrollvirksomheten synes å ha blitt mer systematisk. Tokthyppigheten og virksomhetens generelle innretning vil som før kunne variere fra operasjonsområde til operasjonsområde, avhengig av det lokale utfordringsbildet og prioriteringene på føderalt og regionalt nivå.

På noen områder, eksempelvis maritim grensekontroll og kontroll med etterlevelse av nasjonal lovgivning i russisk territorialfarvann, i russisk økonomisk sone og på russisk kontinentalsokkel, er kystvakten nå mer eller mindre enerådende som oppgaveløser. Gjennomføringen av fiskeriinspeksjoner på sjøen er for eksempel kystvaktens domene. På andre områder løses oppgavene i samarbeid med - eller ved at kystvakten støtter - andre statlige etater. Eksempler på det siste er søk og redning, som også tilligger marinen (VMF) og Kriseministeriet (MTsjS), og oppgaver relatert til tollkontroll og bekjempelse av smugling, som også utføres av tollmyndighetene.

Når det gjelder virksomhetens omfang og oppnådde resultater, pleier kystvaktens ledelse fra tid til annen å gå ut med opplysninger om antall gjennomførte inspeksjoner, oppbringelser, beslag, episoder som har ført til bruk av våpenmakt, antall personer i havsnød som er blitt reddet osv. Slike statistiske data blir gjerne formidlet via FSBs pressetjeneste. Ifølge en pressemelding datert 22. mai 2013 (FSB 2013), gjennomførte den russiske kystvakten i løpet av 2012150 oppbringelser. Det ble i samme periode tatt beslag i fire russiske og ni utenlandske fartøyer, 1700 tonn ulovlige fangster av fisk og krabbe ble inndratt (en økning på 5\% fra året før), og det ble ilagt bøter for mer enn 240 millioner rubler (ibid.). Tilsvarende tall for 2011 var 170 oppbringelser, beslagleggelse av fem russiske og ti utenlandske fartøyer, inndragelse av 1600 tonn ulovlig fanget fisk og krabbe og ileggelse av bøter på til sammen 400 millioner rubler (Valer'ev \& Vladimirova 2012: 8-9). «Administrative forføyninger» (bøteleggelser, advarsler etc.) ble for øvrig truffet overfor 5000 personer i 2011 og 5500 i 2012 (ibid.; FSB 2013). 
Den russiske kystvaktens kontrollvirksomhet på fiskeriområdet har mange likhetstrekk med kontrollvirksomheten som andre lands kystvakter utøver, men det er også forskjeller i virksomhetens organisering og innretning. Russiske fiskeriinspeksjoner, både på sjøen og i havn, har tradisjonelt vært svært «dokumentorienterte». Den fysiske kontrollen av hvorvidt fangsten om bord på de inspiserte fartøyene faktisk er i samsvar med det som er oppgitt i de aktuelle dokumentene, har ikke alltid vært like grundig. Dette kom for eksempel frem i forbindelse med en norsk og russisk parallellrevisjon av fiskeriforvaltningen i nord for noen år siden, hvor det også ble påpekt at fysisk kontroll av fangst ved landing i Russland bare ble gjennomført ved mistanke om ulovligheter (Riksrevisjonen 2011: 45).

Hovedtyngden av de fiskerirelaterte lovbruddene - hele $89 \%$, ifølge en artikkel i FSB-tidsskriftet $\mathrm{Za} i$ protiv (Manakov 2012: 16) - skjer i farvannene utenfor den russiske stillehavskysten, det vil si havområdene utenfor regionene Sakhalin (som inkluderer øygruppen Kurilene), Kamtsjatka, Primorje og Khabarovsk, hvor blant andre fiskere fra Japan, Kina og Sør-Korea opererer. Det er også på stillehavskysten at den russiske fiskeriaktiviteten er mest omfattende og uttaket størst. Deler av Det kaspiske hav, særlig områdene utenfor Dagestan, Kalmykia og Astrakhan, nevnes også blant "problemregionene» (ibid.). ${ }^{5}$ I Barentshavet og øvrige russiske arktiske farvann synes tyvfisket å være mindre omfattende enn i nevnte regioner, og mindre omfattende enn det var på slutten 1990-tallet og i første halvdel av 2000-tallet. Ifølge tall fra Fiskeridirektoratet ble Russlands torskekvote i Barentshavet årlig overfisket med i størrelsesorden 50-80\% i perioden 2002-2006 (Hønneland 2012: 75).

Graden av maktbruk fra den russiske kystvaktens side, overfor russiske eller andre lands fartøyer, varierer fra region til region, men mange av episodene, og flertallet av de alvorlige episodene, finner sted på den russiske østkysten. Kystvakten har myndighet til å bruke væpnet, og i ytterste fall dødelig, makt (Boltenkov 2013: 28). Det hører imidlertid til sjeldenhetene at skudd blir avfyrt av eller fra russiske kystvaktfartøyer, og når det skjer, er det oftest i form av varselskudd. Slike episoder blir rutinemessig etterforsket i ettertid. I 2010 var det for eksempel elleve episoder der skudd ble avfyrt mot lovbrytere på sjøen. Samtlige av de involverte tjenestemennene ble vurdert å ha opptrådt i samsvar med gjeldende instruks (ibid.).

Kystvakten yter også ulike former for bistand til fiskere og andre sjøfarende. Ambisjonen er å ha en mest mulig kontinuerlig tilstedeværelse i de mest besøkte og trafikkerte farvannene, slik at man på kort varsel kan gripe inn om noen skulle havne i problemer grunnet dårlige værforhold eller ulykkeshendelser. Årlig redder kystvakten om lag 150 personer i kritiske situasjoner på sjøen (Valer'ev \& Vladimirova 2012: 8). Der geografien tilsier at det er formålstjenlig, ivaretar Russland sine funksjoner innenfor søk og redning i samarbeid med andre staters kystvakter og redningstjenester. I oktober 2015 bisto for eksempel en Murmanskbasert taubåt et norsk tankskip som hadde fått tauverk i propellen og ble liggende å drive i dårlig vær øst i Barentshavet (B-port 8. oktober 2015). Søk- og

\footnotetext{
${ }_{5}^{5}$ Dette dreier seg særlig om ulovlig størfiske utført av lokale kriminelle nettverk. For detaljer, se Sytsjeva 2011.
} 
redningsavtalen som i mai 2011 ble inngått mellom de åtte medlemslandene i Arktisk Råd (Arctic Council 2011), og som trådte i kraft i januar 2013 (Justisdepartementet 2013), har bidratt til å skape et styrket rammeverk for slikt samarbeid. De globale klimaendringene og issmeltingen i Polhavet tilsier at den totale oppdragsmengden på området søk og redning vil kunne øke i årene som kommer. Samtidig er det lite som tyder på at skipstrafikken i regionen vil øke dramatisk frem mot 2020.

Deler av havområdene som omgir Den russiske føderasjon er i tillegg utsatt for smugling, herunder menneskesmugling og forsøk på innførsel eller utførsel av narkotika, våpen og andre ulovlige varer. Avdekking og bekjempelse av denne type virksomhet inngår også i kystvaktens oppdragsportefølje. Ifølge kystvaktens stedfortredende sjef, kontreadmiral Aleksej Vol'skij, avverget kystvakten i 2011 rundt 35 smuglerforsøk (Valer'ev \& Vladimirova 2012: 9). Omfanget av smuglervirksomheten skal dette året ha blitt betydelig redusert sammenlignet med foregående år. Samme år avdekket kystvakten også 218 forsøk på sjøveis menneskesmugling. Tilsvarende tall for 2010 var 548. Nedgangen i antallet avdekkede forsøk på menneskesmugling indikerte ifølge Vol'skij at omfanget av denne virksomheten var på vei nedover, blant annet takket være målrettet innsats fra kystvaktens side (ibid.).

Det å føre oppsyn med Den russiske føderasjons yttergrenser, inkludert de maritime grensene, er en formidabel oppgave som stiller store krav til de som til enhver tid patruljerer dem - på land, på elver og innsjøer, og ikke minst på sjøen. Her spiller kystvakten en viktig rolle som statens oppsynsmann og myndighetsutøver. Den russiske føderasjons grense er $60932 \mathrm{~km}$ lang, hvorav $38807 \mathrm{~km}$ er sjøgrense, $7141 \mathrm{~km}$ er grense langs elver og $475 \mathrm{~km}$ er grense som krysser innsjøer (Boltenkov 2013: 27). Hele 70\% av Russlands grenser går med andre ord gjennom vann, og størstedelen av den maritime grensen ligger i nord.

\section{Nordområdene og Arktis}

Den russiske kystvaktens aktiviteter i de nordlige havområder er innrettet med utgangspunkt i prioriteringene som ligger i strategidokumenter som Arktis-strategien fra 2008 (Pravitel'stvo Rossijskoj Federatsii 2008), 2013-strategien for utvikling av Russlands arktiske sone (Pravitel'stvo Rossijskoj Federatsii 2013) og det føderale målprogrammet «Den russiske føderasjons statsgrense 2012-2020» (Pravitel'stvo Rossijskoj Federatsii 2012). I sistnevnte program ble det blant annet trukket opp planer for utbygging av grenseinfrastrukturen i Russlands arktiske kystsone, med fokus på elleve nærmere spesifiserte objekter.

I perioden frem mot 2020 legges det opp til at den russiske kystvakten vil bli tilført fire nye havgående fartøyer for operasjoner i Arktis, ifølge et nylig intervju med sjefen for FSBs grensevakttjeneste, generaloberst Nikolai Rybalkin (Interfax 27. mai 2013). Trolig er det her tale om isforsterkede og helikopterbærende fartøyer av Okean-klassen. Disse skal etter planen operere både i den vestlige delen av Russlands arktiske havområder, formodentlig med base i Murmansk, samt i det nordligste stillehav, Beringhavet og havområdene nord og øst for Beringstredet, formodentlig fra Petropavlovsk-Kamtsjatskij. Dersom de nye fartøyene av Okean-klassen viser seg 
å fungere etter forventningene, vil man vurdere å utvide klassen med inntil ni enheter i tillegg de fire som allerede er besluttet anskaffet (Nikolsky 2013: 25; Jegorov 2015).

Hovedtyngden av den russiske kystvaktens patruljevirksomhet i nord er konsentrert om Barentshavet. Det er også i de vestlige (og mest isfrie) delene av det maritime ansvarsområdet til grensedirektoratet i Murmansk at fiskeriene og skipstrafikken er mest omfattende. I tillegg til å patruljere Russlands egne maritime jurisdiksjonsområder i nordvest, har russiske kystvaktfartøyer i senere år også vært observert i Fiskevernsonen utenfor Svalbard. Dette er et område der mange russiske fartøyer driver fiske, kanskje særlig i farvannene rundt Bjørnøya. Offisielt begrunnes den russiske kystvaktens periodiske tilstedeværelse i disse havområdene med et behov for å utøve flaggstatskontroll av de russiske fartøyene som opererer der. Det er med andre ord ikke tale om regulære fiskeriinspeksjoner, som er kyststatens, det vil si Norges, domene. Samtidig kan det ikke legge skjul på at Norges og Russlands ulike og til dels motstridende syn på sonens folkerettslige status representerer en potensiell utfordring i utøvelsen av norsk kyststatsjurisdiksjon i havområdene rundt Svalbard.

Ifølge sjefen for den statlige sjøinspeksjonens (GMIs) avdeling i Murmansk, kommandør Dmitrij Skiba, består fiskeflåten i den nordlige fiskeriregionen (Severnyj promyslovyj rajon) av mer enn 300 fartøyer (Putejev 2008: 34). I 2008 hadde 142 russiske selskaper (rederier) kvote i de nordlige havområdene, ytterligere 87 selskaper drev med kystfiske, og 11 selskaper var involvert i fangst av Kamtsjatka-krabbe (ibid.). I de første åtte månedene av dette året (2008) ble det i kystvaktens regi gjennomført i størrelsesorden 3200 inspeksjoner i Barentshavet og Kvitsjøen. De langt fleste av inspeksjonene skjedde i havner eller kystnære transittpunkter, mens rundt 500 fartøyer ble inspisert på sjøen. Som resultat av inspeksjonene ble det avdekket 120 uregelmessigheter, hvorav 90 resulterte $\mathrm{i}$ «administrative forføyninger» (primært bøter og beslag) og millioner av rubler i inntekter til statskassen (ibid.).

Sjefen for GMIs avdeling i Murmansk er opptatt av å skape en god profesjonskultur innen etaten og forebygge korrupsjon i egne rekker (se intervju i Putejev 2012: 21-22). Rett som det er skjer det at kystvaktens personell blir tilbudt og noen ganger faller for fristelsen til å ta imot - penger for å se gjennom fingrene med lovbrudd eller slippe båter i land med ulovlige fangster. I 2009 ble det for eksempel avdekket et tilfelle der et kriminelt nettverk skal ha betalt USD 20000 for å få lande en ulovlig fangst på rundt 100 tonn i den lukkede byen Safonovo nord for Murmansk (Pettersen 2009). Omfanget av slik virksomhet er det vanskelig å si noe om for en utenforstående, men mye tyder på at det er mindre i dag enn det var det før 1998, da Fiskeribyrået satt med kontrollmyndigheten. På den annen side er bakmennenes betalingsevne (og -vilje) sannsynligvis vel så stor i dag som det den var på 1990-tallet, da fiskebestandene og ressurstilgangen var mindre. Dette, kombinert med den gjenstridige og generelt utbredte korrupsjonskulturen innen russisk samfunns- og næringsliv, herunder blant sentrale kommersielle aktører i Murmansk og Arkhangelsk, tilsier at korrupsjonsproblemet innen fiskerisektoren på ingen måte er løst, og heller ikke vil bli det med det første.

Selv om tyvfisket i Barentshavet har gått ned, blant annet som resultat av mer systematisk og målrettet inspeksjonsvirksomhet og styrket internasjonalt samarbeid, 
kan det ikke underslås at den russiske kystvakten fortsatt har en del å stri med på kapasitetssiden. Blant materiellet som tjenestemennene i Murmansk ønsker seg, er moderne fartøyer og overføringsmidler (lettbåter og helikoptre), tidsmessige kommunikasjonssystemer og bærbare computere med egnet programvare. Grunnet trange budsjetter har flere av inspektørene selv måtte kjøpe redningsdrakter en nødvendighet for å kunne arbeide noenlunde trygt på sjøen - for penger fra egen lomme (Putejev 2008: 37). Sett i forhold til operasjonsområdets størrelse, oppgavespekterets omfang og verdien av naturressursene som den forvalter, fremstår kystvaktens Murmansk-baserte flåte av havgående fartøyer (fire-fem i tallet) som både liten, nedslitt og til dels umoderne. Dette legger også betydelige begrensninger på flåtens evne til å kunne drive effektiv og kontinuerlig ressurskontroll, kanskje særlig i de mest fjerntliggende farvannene. I tillegg synes det å være en begrensende faktor, både her og andre steder, at kystvaktens forhold til andre russiske myndighetsaktører, herunder fiskerimyndighetene og deres lokale representanter, ikke er like åpent som i mange andre land.

Når det gjelder ulovlig fiske fra fremmede staters fartøyer i russiske farvann, så synes dette å være et langt mindre problem i nordområdene enn det er på den russiske stillehavskysten. Utenlandske fartøyer som fisker i russisk økonomisk sone $\mathrm{i}$ Barentshavet, har gjerne med seg en inspektør fra GMI under oppholdet på russisk side (Putejev 2012: 23). Men fra tid til annen oppstår det konflikter i forbindelse med inspeksjon eller oppbringelse av andre lands fartøyer. Blant de mer omtalte i så måte er oppbringelsen av det litauiske fartøyet «Juros Vilkas» i Barentshavet 18. september 2014, som vakte sterke reaksjoner, ikke bare på litauisk myndighetshold, men også fra EU. Oppbringelsen skjedde ifølge litauerne i internasjonalt farvann (Smutthullet), og fartøyet, som hadde et mannskap på 28, ble ført inn til Murmansk av den russiske kystvakten. Russisk UD hevdet at fartøyet hadde drevet ulovlig krabbefiske i russisk økonomisk sone, og at kystvakten på dette grunnlag hadde iverksatt en såkalt «hot pursuit» med påfølgende arrestasjon av fartøyet (MID 2014). Fartøyet ble frigitt først noen uker senere, mot en kausjon på EUR 2,25 millioner (The Lithuania Tribune 7. oktober 2014).

Forebyggelse av terrorisme og ivaretakelse av sikkerheten til installasjoner på kontinentalsokkelen og havbunnen inngår også i kystvaktens oppdragsportefølje. I den russiske delen av nordområdene og Arktis er det foreløpig få sokkelinstallasjoner, så oppdragsmengden på dette området er trolig nokså begrenset. En installasjon som $\mathrm{i}$ senere år har tiltrukket seg en viss oppmerksomhet fra utenlandske miljøaktivisters side, og dermed generert en del arbeid for kystvakten og FSB, er Prirazlomnoje-plattformen i Petsjorahavet. Denne ble installert i 2011 og satt i produksjon høsten 2013. I august 2012 og september 2013 forsøkte personell fra det Greenpeace-eide og nederlandsk-flaggede fartøyet «Arctic Sunrise» å ta seg inn til, og opp på, plattformen for å demonstrere mot virksomheten og mot manglende russisk oljevernberedskap i Arktis. Ved sistnevnte anledning gjennomførte personell fra FSB en væpnet bording av fartøyet ved hjelp av helikopter og med støtte fra det Murmansk-baserte kystvaktfartøyet «Ladoga». Forut for bordingen hadde "Ladoga» avfyrt elleve varselskudd og truet med å åpne ild mot «Arctic Sunrise» dersom 
fartøyet ikke stanset (Oude Elferink 2014: 251). Demonstrantene ble til slutt pågrepet og «Arctic Sunrise» ble tauet inn til Murmansk.

Fra den russiske regjeringens side har man lenge ønsket å slå hardt ned på slik virksomhet, og planen etter episoden i september 2013 var å sikte Greenpeacedemonstrantene for pirateri, som i Russland har en strafferamme på inntil 15 år (Walker 2013). I oktober, etter at Putin hadde forsøkt å tone ned saken, ble siktelsen endret til «hooliganisme», som har en atskillig kortere strafferamme. De 30 aksjonistene ble etter en parlamentsbeslutning gitt amnesti og løslatt ved juletider samme år (Gutterman 2013). Fartøyet «Arctic Sunrise» ble imidlertid ikke frigitt før i begynnelsen av juni 2014, om lag ni måneder etter arrestasjonen (Vidal 2014). Nederlandske myndigheter mente at russerne hadde overreagert $i$ forbindelse med aksjonen mot Greenpeace-skipet og at Russland under oppbringelsen hadde handlet i strid med Havretten. Dette fikk de langt på vei medhold i av Den faste voldgiftsdomstolen i Haag ved en domsslutning i august 2015 (Permanent Court of Arbitration 2015). Russland på sin side har avvist så vel Haag-domstolens jurisdiksjon i saken som innholdet i domsslutningen og flaggstatens erstatningskrav. Sett fra russisk side var de sentrale momentene i saken at «Arctic Sunrise» ikke hadde etterkommet kystvaktens gjentatte pålegg om å avbryte aksjonen, at fartøyets lettbåter hadde tatt seg ulovlig inn i sikkerhetssonen rundt plattformen og at demonstrantene derved hadde eksponert både plattformen og seg selv for betydelig fare.

\section{Det norsk-russiske kystvaktsamarbeidet}

Utbyggingen av et bredt, målrettet og langsiktig samarbeid med Russland på områder av felles interesse har vært en hovedlinje i norsk utenrikspolitikk etter den kalde krigen. Dette samarbeidet har også omfattet samarbeidsaktiviteter på det militære området, inkludert felles marineøvelser («Pomor») og besøksutveksling mellom militære hovedkvarter, skoler og avdelinger i de to land. Disse aktivitetene, som primært har funnet sted innenfor rammen av den årlige tiltaksplanen for bilateralt forsvarsrelatert samarbeid, ble på norsk initiativ stilt i bero etter Russlands militære intervensjon på Krim i februar-mars 2014. Dette ble offisielt meddelt russiske myndigheter 25. mars 2014 (Forsvarsdepartementet 2014). Kort tid etter, i forbindelse med sitt utenriksministermøte i Brussel 1. april samme år, vedtok også Nato å innstille alt praktisk samarbeid med Russland, militært så vel som sivilt (Nato 2014).

Etter den folkerettsstridige okkupasjonen og anneksjonen av Krimhalvøya har Russland også bidratt til en destabilisering av situasjonen i Øst-Ukraina, gjennom sin omfattende støtte til prorussiske væpnede grupperinger i Donetsk og Luhansk. Suspensjonen av det militære/forsvarsrelaterte samarbeidet mellom Norge og Russland, og mellom Nato og Russland, er i lys av dette blitt ytterligere forlenget. Mye taler for at dette vil kunne bli en langvarig tilstand.

Nedfrysningen av Norges militære samarbeid med Russland etter intervensjonen i Ukraina innebærer at samarbeidet innenfor politi-, justis- og «soft security»-sfæren i 
dag utgjør en relativt sett større del av det totale samkvemmet mellom de to land. På norsk side har man hele tiden ønsket å videreføre kystvakt- og redningssamarbeidet med Russland. Det synes å være en utbredt oppfatning også på russisk side at noen samarbeidsområder er «for viktige» til å bli påvirket av svingninger i Russlands forhold til Vesten. Forebyggelse av tyvfiske og ivaretakelse av sikkerheten til sjøfarende er åpenbart blant disse. Slikt samarbeid kan også gi bredere sikkerhetspolitiske gevinster, ved at det bidrar til å bygge tillit og mellomfolkelig sympati på regionalt og mellomstatlig nivå. Dette er særlig viktig i en situasjon der forholdet mellom øst og vest ellers preges av økende frykt, mistro og mistillit.

Det norsk-russiske forvaltnings- og kontrollsamarbeidet på fiskeriområdet er organisert som et firepartssamarbeid der både de to lands fiskerimyndigheter (henholdsvis Fiskeridirektoratet og Rosrybolovstvo) og de to lands kystvakter deltar. Kystvaktene er representert i flere bilaterale samarbeidsfora på fiskeriområdet, ettersom mye av aktiviteten på dette området foregår innenfor rammen av møtestrukturen under Den blandede norsk-russiske fiskerikommisjon. På kommisjonsog utvalgsmøtene diskuteres utfordringer, problemstillinger og løsninger innen ressurskontroll av marine arter så vel som samarbeid på andre områder. Også utenfor rammen av fiskerikommisjonens arbeid er det jevnlig kontakt mellom de to lands kystvakter og regionale operasjonssentraler, og gjensidige fartøysbesøk tilstrebes gjennomført på årlig basis, vekselvis i Russland og i Norge. I forbindelse med fartøysbesøkene avholdes det gjerne også et møte mellom sjefen for Forsvarets operative hovedkvarter $(\mathrm{FOH})$ og sjefen for FSBs grensedirektorat i Murmansk, som kommer i tillegg til øvrige arbeidsmøter på dette nivået, eventuelt nivået under på norsk side (NK FOH).

Innholdet i det løpende samarbeidet mellom de to lands fiskerimyndigheter og kystvakter fremgår av «Memorandum om samarbeidsordninger om kontroll mellom Det norske fiskeridirektoratet, Den norske kystvakten, Rosrybolovstvos territorielle administrasjon for Barentshavet og Kvitsjøen og Grensedirektoratet i Russlands føderale sikkerhetstjeneste i Murmansk fylke» (Memorandum 2013). I memorandumet omtales fem nærmere spesifiserte samarbeidsområder, hvorav tre relaterer seg til temaet utveksling av informasjon, ett til operativt samarbeid og ett til kontrollsamarbeid i reguleringsområdet til Den nordøstatlantiske fiskerikommisjon (NEAFC).

Informasjonsutvekslingen mellom de to lands kystvakter og fiskerimyndigheter dreier seg om forhold som åpning og stenging av fiskefelt, data i forbindelse med satellittsporing av fartøyer, landingsopplysninger og kvoter på fartøynivå. Videre utveksles det informasjon om kontrollresultater og iverksatte tiltak ved overtredelser, samt informasion ved mistanke om ulovlig fiskeri-aktivitet, andre kontrollopplysninger og kontrollerfaringer som anses å være av nytte eller relevans for den annen part. Slik informasjonsutveksling kan skje under bilaterale møter eller fortløpende via telefon, telefaks eller e-post.

Det operative samarbeidet har som siktemål å effektivisere kontrollvirksomheten, blant annet gjennom utvikling av nye kontrollmetoder og videreutvikling av eksisterende. Målet med dette er å redusere omfanget av ulovlig og uønsket 
virksomhet. I memorandumet fra 2013 legges det opp til jevnlig («minst to ganger per år) samarbeid om utveksling av inspektører. Dette innebærer at de kompetente organer etter avtale kan utveksle inspektører på hverandres fartøyer. Disse kan delta som observatører under fartøysinspeksjoner i den annen parts økonomiske sone eller havner, eller ved landinger i tredjeland. I tillegg kan det utveksles inspektører som observatører på fartøy i forbindelse med stenging eller åpning av fiskefelt. Som hjemlet i memorandumet giennomføres det også utvekslinger mellom den norske kystvakten og FSBs regionale grensedirektorat på land (dvs. operasjonssentralene, lokalisert henholdsvis på Sortland og i Murmansk).

Når det gjelder samarbeidet $\mathrm{i}$ reguleringsområdet til NEAFC, det vil si havområdene som ligger utenfor landenes 200-mils økonomiske soner (primært Smutthullet og Smutthavet), så er innholdet i dette ikke nærmere spesifisert i memorandumet fra 2013. Men det faktum at et punkt om samarbeid i NEAFCområdet er inkludert i memorandumet indikerer at fagmyndighetene på norsk og russisk side også her har en ambisjon om å samarbeide innenfor kontrollregimets rammer og intensjoner. I tillegg til Norge og Russland involverer NEAFC-samarbeidet EU, Danmark og Island («contracting parties») samt ikke-medlemmene («cooperating non-contracting parties») Canada, New Zealand og den karibiske øystaten Saint Kitts og Nevis.

Erfaringene med ovennevnte samarbeidsordninger, hvorav noen har eksistert siden midten av 1990-tallet, må sies å ha vært gode. Samarbeidet har bidratt til en effektivisering av kontrollregimet, harmonisering av inspeksjonsprosedyrer og utbygging av gode personlige relasjoner både på sjefs- og utøvende nivå. Operasjonssentralene i Sortland og Murmansk har i dag ukentlig kontakt. Også ledelsen for kystvakten på begge sider kan ved behov kontakte hverandre på kort varsel. Slike kommunikasjonskanaler er godt egnet til å oppklare misforståelser og forebygge konflikter knyttet til kontrollvirksomheten eller andre deler av kystvaktenes virke.

Som et supplement til det regionale kystvaktsamarbeidet i det nordatlantiske området (NACGF) og det nordlige stillehav (NPCGF), er det nylig blitt etablert et eget kystvaktforum for Arktis, kjent som the Arctic Coast Guard Forum (ACGF). Bakgrunnen for dette initiativet er å finne i det faktum at mange av de nåværende og antatte fremtidige utfordringene i Arktis er sirkumpolare av natur, og at Arktisk Råds åtte medlemsland mener de kunne hatt nytte av et eget forum for dialog og samarbeid på kystvaktområdet. Russisk UD, FSB og den russiske kystvakten har fra starten av stilt seg positiv til idéen. Et første ACGF-møte på ekspertnivå ble avholdt i Canada i mars 2014, riktignok uten russisk deltakelse. Forumet ble formelt etablert under et regionalt møte på sjefsnivå, avholdt ved det amerikanske kystvaktakademiet i New England, Connecticut, 30. oktober 2015 (Forsvarsdepartementet 2015). Ved sistnevnte anledning var Russland representert ved kystvaktsjef Jurij Aleksejev. Hvordan det arktiske kystvaktforumet vil utvikle seg i årene som kommer, gjenstår å se. Tanken er at ledelsen av forumet skal gå på omgang blant de åtte deltakerne, parallelt med rotasjonen i formannskapet for Arktisk Råd. Formannskapet i Arktisk Råd innehas for tiden (2015-2017) av USA. 


\section{Oppsummering og konklusjon}

Den russiske kystvakten må fortsatt sies å være under oppbygging. Mye er oppnådd på de ni årene som er gått siden etableringen i 2007, både organisatorisk og hva gjelder virksomhetens resultater. Men det er også mye som gjenstår før tjenesten kan sies å besitte de kapasiteter og den kompetanse og erfaring som fremtidens oppgaver vil kreve. I denne avsluttende seksjonen er det naturlig å vende tilbake til spørsmålet som ble stilt $\mathrm{i}$ innledningen - hvordan den russiske kystvaktens samlede evne til oppgaveløsning kan tenkes å utvikle seg i perioden frem mot 2020. I denne forbindelse er det også naturlig å se nærmere på perspektivene for samarbeidet mellom den russiske kystvakten og nabolandenes kystvakter, inkludert den norske.

Som ivaretaker av Russlands rettigheter og interesser i det maritime domenet, som utøver av nasjonal jurisdiksjon, og ikke minst som koordinator av andre myndighetsorganers kontroll- og tilsynsvirksomhet i russisk territorialfarvann, russisk økonomisk sone og på russisk kontinentalsokkel, står den russiske kystvakten i en særstilling. Russlands kystvakt er et law enforcement-organ, snarere enn en militær struktur. Den inngår ikke i det militære kommandosystemet, iallfall ikke i fredstid. Den russiske kystvakten har imidlertid rett til å utøve tvangsmakt overfor lovbrytere på sjøen, uavhengig av om de er russiske eller utenlandske. Mange av kystvaktens fartøyer er bevæpnede, og noen av de større fartøyene er utstyrt med våpensystemer som tilsvarer dem man vil finne på marinens fartøyer. Kystvakten disponerer også grovkalibrede håndvåpen, slik grensevakten på land har. Samtidig bør det understrekes at maktmidlene som kystvakten råder over, har sine begrensninger, både når det gjelder rekkevidde, presisjon og ødeleggelsesevne. Fartøyene er ikke bygget for militær krigføring, og personellet er heller ikke utdannet eller trent for dette.

Omfanget og alvorlighetsgraden av utfordringene som den russiske kystvakten står overfor i sitt daglige virke, varierer fra region til region. Det samme gjør omfanget - og vellykketheten - av samarbeidet mellom den russiske og andre lands kystvakter i de ulike operasjonsteatrene. Havområdene i øst (Stillehavskysten) og sør (Svartehavet og Det kaspiske hav) virker å være mer utsatte for uønsket virksomhet, herunder ulovlig, uregistrert og uregulert (IUU) fiske, enn havområdene i nord (Barentshavet og Norskehavet) og vest (Østersjøen). Det mellomstatlige samarbeidsklimaet i nord og vest fremstår også som bedre enn det gjør i sør og øst, hvor det også finnes flere og mer presserende maritime grensetvister (eksempelvis Kurileneproblematikken).

Dette gjenspeiler seg også i den russiske kystvaktens styrkemessige prioriteringer, i den forstand at virksomheten i de østlige havområdene etter alt å dømme legger beslag på en betydelig større del av kystvaktens driftsbudsjett enn virksomheten i vest. Det synes for eksempel å være betydelig flere kystvaktfartøyer, tokt og fiskeriinspeksjoner i farvannene utenfor den russiske stillehavskysten enn det er i for eksempel Barentshavet. Dette vil ventelig være situasjonen også i årene som kommer. Samtidig er det grunn til å tro at den russiske kystvaktens operative evne i nord 
(inkludert nordvest) vil bli forsøkt styrket i årene som kommer, spesielt gjennom den pågående anskaffelsen av Okean-klassen.

Den russiske kystvaktens finansielle situasjon er trolig blitt bedre etter at grensevakttjenesten i 2003 ble innlemmet i FSB. Det kan også virke som om kystvaktens oppgaver står høyere på den russiske regjeringens prioriteringsliste i dag enn de gjorde for bare fem eller ti år siden. Samtidig er det åpenbart at det pågår en kontinuerlig kamp om ressurser, både innad i FSB og mellom FSB og de andre maktstrukturene nå føderalt nivå. Når det gjelder materiellinvesteringer, kan det virke som om Russlands væpnede styrker i det siste tiåret er blitt høyere prioritert enn styrkene som ligger under FSB. Kystvaktens anskaffelsesplan for perioden frem mot 2020 er blitt innarbeidet i det statlige våpenprogrammet for samme periode ( $\mathrm{GPV}$ 2020»), men ressursbruken på de «ikke-militære» strukturene, herunder kystvakten, utgjør en relativt begrenset del av programmet som helhet. Den politiske viljen til å bruke penger på modernisering av kystvakten er med andre ord ikke like stor som viljen til å bruke penger på modernisering av marinen og andre deler av det russiske forsvaret.

Oppgavene som de russiske kystvaktstyrkene er satt til å løse, er både mangeartede, sammensatte og komplekse. Som denne studien har vist, er mye av virksomheten innrettet mot ressurskontroll og håndhevelse av gjeldende nasjonale forskrifter og internasjonale avtaler på fiskeriområdet. Selv om det ulovlige fisket i havområdene som omgir Den russiske føderasjon synes å gå ned, kanskje særlig i de nordlige havområder, er det intet som tyder på at fiskerioppsyn som sådan vil bli en mindre viktig oppgave for den russiske kystvakten i perioden frem mot 2020. Det at fiskeriene i nord gradvis forflytter seg til nye områder på grunn av økende havtemperatur og redusert isdekke, vil tvert imot kunne bidra til å gjøre fiskerioppsynsoppgaven mer krevende $\mathrm{i}$ årene som kommer. Økt skipstrafikk i farvannene langs den nordlige sjørute, og en eventuell økning av olje- og gassvirksomheten på Russlands kontinentalsokkel, vil også kunne få betydning for den russiske kystvaktens fremtidige oppgaveportefølje og virksomhet.

Den russiske kystvaktens evne til oppgaveløsning i perioden frem mot 2020 vil ikke bare avhenge av oppgaveporteføljens utvikling og den videre fremdrift i implementeringen av kystvaktens anskaffelsesplan. Kanskje vel så viktig, sett fra omverdenens side, er utviklingen av samarbeidet mellom den russiske og andre staters kystvakter. Som nevnt innledningsvis, løser den russiske kystvakten i dag sine oppgaver dels alene, dels sammen med andre russiske etater, og dels sammen med nabolandenes kystvakter, deriblant den norske. Det fremtidige forholdet til nabolandene og deres kystvakter vil med andre ord kunne få stor betydning for Russlands evne til å ta vare på de levende marine ressursene i russiske og nærliggende internasjonale havområder. En opprettholdelse, styrking og videreutvikling av kystvaktsamarbeidet i de ulike områdene som den russiske kystvakten opererer $\mathrm{i}$, må slik sett antas å være i både Russlands og nabolandenes, inkludert Norges, langsiktige interesse. 


\section{Litteratur}

Arctic Council (2011) «Agreement on Cooperation on Aeronautical and Maritime Search and Rescue in the Arctic». Undertegnet i Nuuk, Grønland, 12. mai 2011. Tilgjengelig på www.ifrc.org/docs/idrl/N813EN. pdf. Lesedato 4. november 2015.

Boltenkov, Dmitry (2013) «The Russian Coast Guard». Moscow Defense Brief (3): 27-29.

Desnitskaja, Jelizaveta (2015) «Arktika - pod sjtsjitom. Pogranitsjnym». Murmanskij Vestnik 14. august. Tilgjengelig på www.mvestnik.ru/shwpgn.asp?pid=201508145. Lesedato 5. januar 2016.

Forsvarsdepartementet (2015) «Etablerer Arktisk kystvaktforum». Nyhetsmelding, 30. oktober. Tilgjengelig på www.regjeringen.no/no/aktuelt/etablerer-arktisk-kystvaktforum/id2459821/. Lesedato 4. november 2015.

Forsvarsdepartementet (2014) «Norge innstiller planlagte militære aktiviteter med Russland». Pressemelding no. 25, 25. mars. Tilgjengelig på www.regjeringen.no/nb/aktuelt/Norge-innstiller-planlagte-militareaktiviteter-med-Russland-/id753887/. Lesedato 4. november 2015.

FSB (2013) «O dejatel'nosti Departamenta Beregovoj okhrany Pogranitsjnoj Sluzjby FSB Rossii v 2012 godu». Pressemelding, 22. mai. Tilgjengelig på http://fish-seafood.ru/news/detail.php?ID=85226. Lesedato 11. februar 2014 (siden er ikke lenger aktiv).

FSB (2012) FSB: $Z a$ i protiv (3) (temanummer om kystvakten), tilgjengelig på http://osfsb.ru/ press-center/m/default.aspx. Lesedato 4. november 2015.

Gutterman, Steve (2013) «Russian Amnesty to Benefit Pussy Riot, Greenpeace 30». Reuters 19. desember.

Hønneland, Geir (2012) Making Fisheries Agreements Work: Post-Agreement Bargaining in the Barents Sea. Cheltenham: Edward Elgar Publishing.

Hønneland, Geir (2003) Utfordringer i fiskerisamarbeidet med Russland. Notat, 24. juni. Tilgjengelig på http:// nordutvalg.npolar.no/Dokumenter/Honneland1.pdf. Lesedato 4. november 2015.

Jegorov, Ivan (2015) «Granitsa na plavu». Rossijskaja gazeta 28. mai.

Justisdepartementet (2013) «Styrket redningssamarbeid i Arktis». Pressemelding no. 8, 18. januar. Tilgjengelig på www.regjeringen.no/no/aktuelt/styrket-redningssamarbeid-i-arktis/id712320/. Lesedato 4. november 2015.

Jørgensen, Anne-Kristin \& Geir Hønneland (2013) «In cod we trust: Konjunkturer i det norsk-russiske fiskerisamarbeidet». Nordisk Østforum 27 (3): 353-376.

Korostikov, Mikhail (2015) «Rossija pretendujet na 1,2 mln kv. km Arktiki». Kommersant 4. august.

Manakov, Aleksej (2012) «V interesakh gosudarstva». FSB: Za i protiv (3): 14-19.

Memorandum (2013) Memorandum om samarbeidsordninger om kontroll mellom Det norske fiskeridirektoratet, Den norske kystvakten, Rosrybolovstvos territorielle administrasjon for Barentshavet og Kvitsjøen og Grensedirektoratet i Russlands føderale sikkerhetstjeneste i Murmansk fylke. Undertegnet i Murmansk, 11. september 2013.

Ministerstvo inostrannykh del (MID) (2014) «Otvet ofitsial'nogo predstavitel'ja MID A.K. Lukasjevitsja na vopros SMI o zaderzjanii litovskogo rybolovetskogo sudna 'Juros Vilkas'». Pressemelding, 24. september. Tilgjengelig på http://mid.ru/brp_4.nsf/newsline/85CD0A2EF0E1AEA444257D5D0047BBC5. Lesedato 4. november 2015.

Nato (2014) «Statement by NATO Foreign Ministers». Pressemelding no. 062, 1. april. Tilgjengelig på www. nato.int/cps/en/natolive/news_108501.htm. Lesedato 4. november 2015.

Nikolsky, Aleksey (2013) «The Invisible Reform of the Border Guard Service». Moscow Defense Brief (2): 23-26.

Oude Elferink, Alex G. (2014) «The Arctic Sunrise Incident: A Multi-faceted Law of the Sea Case with a Human Rights Dimension». The International fournal of Marine and Coastal Law 29 (2): $244-289$.

Pavlova, Elena (2009) «Vodnyj kordon. Beregovaja okhrana Pogranitsjnoj sluzjby FSB Rossii podvela itogi dvukhletnej raboty». FSB: Za i protiv (3): 6-9.

Permanent Court of Arbitration (2015) Arctic Sunrise Arbitration (Netherlands v. Russia). 14. august. Tilgjengelig på www.pcacases.com/web/sendAttach/1438. Lesedato 4. november 2015.

Pettersen, Trude (2015) «New Maritime Doctrine to Strengthen Arctic Presence». BarentsObserver 28. juli. Tilgjengelig på http://barentsobserver.com/en/arctic/2015/07/new-maritime-doctrine-strengthenarctic-presence-28-07. Lesedato 5. januar 2016.

Pettersen, Trude (2009) «Poachers Bribing Border Guard Staff». BarentsObserver 17. april. Tilgjengelig på http://barentsobserver.com/en/node/19221. Lesedato 5. januar 2016. 


\section{4 | KRISTIAN ÅTLAND}

Pravitel'stvo Rossijskoj Federatsii (2012) Federal'naja tselevaja programma «Gosudarsvennaja granitsa Rossijskoj Federatsii (2012-2020 gody)». Vedtatt 31. mai. Tilgjengelig på www.rosgranitsa.ru/ru/ agency/structure/ugpsogg/news/5215. Lesedato 4. november 2015.

Pravitel'stvo Rossijskoj Federatsii (2008) Osnovy gosudarstvennoj politiki Rossijskoj Federatsii v Arktike na period do 2020 goda $i$ dal'nejsjuju perspektivu. Undertegnet 18. september 2008. Tilgjengelig på www.scrf.gov.ru/ documents/98.html. Lesedato 4. november 2015.

Pravitel'stvo Rossijskoj Federatsii (2013) Strategija razvitija Arktitsjeskoj zony Rossijskoj Federatsii i obespetsjenija natsional'noj bezopasnosti na period do 2020 goda. Vedtatt 20. februar. Tilgjengelig på http://government.ru/ info/18360/. Lesedato 4. november 2015.

Putejev, Konstantin (2008) «Konfiskovat' nel'zia ostavit'». FSB: Za i protiv (3): 30-37.

Putejev, Konstantin (2012) «Tsjtoby ne oskudelo Barentsevo more». FSB: Za i protiv (3): 20-23.

Riksrevisjonen (2011) Riksrevisjonens oppfølging av parallellrevisjonen med Den russiske føderasjons riksrevisjon om forvaltningen av fiskeressursene $i$ Barentshavet og Norskehavet. Dokument 3:8. Tilgjengelig på www. riksrevisjonen.no/rapporter/Documents/2010-2011/Dokument\%203/Dokumentbase_3_8_2010_2011. pdf. Lesedato 4. november 2015.

Sjasjkov, Aleksandr (2012) «Granitsu Rossii jezjegodno peresekajet $135 \mathrm{mln}$ tsjelovek - zamglavy Pogranitsjnoj sluzjby Nikolaj Rybalkin». Itar-Tass 28. mai.

Sytsjeva, Natal'ja (2011) «Sila - ne jedinstvennoje oruzjie v voprosakh bezopasnosti». Fishnews 31. januar. Tilgjengelig på http://fishnews.ru/interviews/182. Lesedato 5. januar 2016.

Valer'ev, Aleksej \& Irina Vladimirova (2012) «Aleksej Vol'skij: Beregovaja okhrana dejstvujet na ostrie problem». FSB: Za i protiv (3): 8-13.

Vidal, John (2014) «Arctic 30: Russia Releases Greenpeace Ship». The Guardian 6. juni.

Walker, Shaun (2013) «Russia to Charge Greenpeace Activists with Piracy over Oil Rig Protest». The Guardian 24. september. 